\title{
Secondary lymphedema of limbs and chikungunya fever
}

\author{
Linfedema secundário de membros e febre chicungunha \\ Marcos Arêas Marques ${ }^{1,2}$ (D), Ana Letícia de Matos Milhomens ${ }^{1}$ (D), Juliana de Miranda Vieira ${ }^{1}$ (D), \\ Fabricius Rocha Cardoso 3 (D), Henrique Jorge Guedes Neto ${ }^{4}$ (D)
}

\begin{abstract}
Certain systemic viral infections can be related to development of vascular complications, such as deep venous thrombosis and lymphedema of lower and upper limbs. These links have been well-established in patients with human immunodeficiency virus (HIV), hepatitis C, or influenza. Recently introduced into the American continent (2013), chikungunya virus is an arbovirus transmitted by mosquitoes of the Aedes genus and is the etiologic agent of chikungunya fever (CF), but its relationship to these vascular complications has not yet been consolidated. However, the CF outbreak that occurred during 2015 and 2016 resulted in the first cases described in the medical literature of acute and chronic vascular complications secondary to infection by this arbovirus. In this report, we describe the case of a patient who developed lymphedema of upper and lower limbs after an episode of CF.
\end{abstract}

Keywords: chikungunya virus; chikungunya fever; lymphedema; complications; chronic disease; arbovirus infections.

\section{Resumo}

Algumas infecções virais sistêmicas podem estar relacionadas ao desenvolvimento de complicações vasculares, como trombose venosa profunda e linfedema de membros inferiores e superiores. Essa relação já está bem estabelecida em pacientes portadores do vírus da imunodeficiência humana (HIV), hepatite Cou influenza. Recentemente introduzido no continente americano (2013), o vírus chicungunha, um arbovírus transmitido pelo mosquito do gênero Aedes e agente etiológico da febre chicungunha $(F C)$, ainda não tem essa relação bem sedimentada. Porém, o surto de $F C$, ocorrido entre 2015 e 2016, fez com que fossem descritos na literatura médica os primeiros casos de complicações vasculares agudas e crônicas secundárias à infecção por essa arbovirose. Neste relato de caso, descrevemos uma paciente que desenvolveu linfedema de membros superiores e inferiores após quadro de FC.

Palavras chaves: vírus chicungunha; febre de chicungunha; linfedema; complicações; doença crônica; infecções por arbovírus.

Como citar: Marques MA, Milhomens ALM, Vieira JM, Cardoso FR, Guedes Neto HJ. Secondary lymphedema of limbs and chikungunya fever. J Vasc Bras. 2019;18:e20190015. https://doi.org/10.1590/1677-5449.190015

\footnotetext{
${ }^{1}$ Universidade do Estado do Rio de Janeiro - UERJ, Rio de Janeiro, RJ, Brasil.

${ }^{2}$ Universidade Federal do Estado do Rio de Janeiro - UNIRIO, Rio de Janeiro, RJ, Brasil.

${ }^{3}$ Instituto Nacional de Câncer, Rio de Janeiro, RJ, Brasil.

${ }^{4}$ Escola Paulista de Medicina, Universidade Federal de São Paulo - UNIFESP, São Paulo, SP, Brasil.

Financial support: None.

No conflicts of interest: declared concerning the publication of this article.

Submitted: June 06, 2018. Accepted: January 29, 2019.
}

The study was carried out at Serviço de Angiologia, Hospital Universitário Pedro Ernesto, Universidade do Estado do Rio de Janeiro (UERJ), Rio de Janeiro, RJ, Brazil. 


\section{INTRODUCTION}

Chikungunya fever (CF) is caused by the chikungunya virus (CHIKV), an arbovirus of the Alphavirus genus that is transmitted to humans via bites by female mosquitoes of the Aedes genus, and was first described in the 1950s in central Africa and later in other African countries and in Asia. ${ }^{1}$ In 2007, CHIKV arrived in Europe, causing a CF outbreak in Italy, and it is believed that from this point onwards dissemination of CHIKV to new territories, such as Australia and the Western hemisphere began to occur. ${ }^{1,2}$ In December of 2013, the Pan American Health Organization published the first notification of autochthonous CHIKV transmission on the American continent. ${ }^{3}$ Clinically, $\mathrm{CF}$ is characterized by abrupt onset of high fever $\left(>38.9^{\circ} \mathrm{C}\right)$, shivering, and photophobia, lasting approximately 7 days. In the majority of cases, patients also develop incapacitating polyathralgia, usually symmetrical, involving hips, elbows, fingers, toes, knees, and ankles, limiting locomotion for months or even years, ${ }^{1-3}$ in addition to maculopapular rash on the trunk, face, and extremities, itching, headaches, tiredness, nausea, vomiting, conjunctivitis, cervical lymphadenopathy, and myalgia. ${ }^{1-3}$ The most common laboratory findings during the acute phase of $\mathrm{CF}$ are leukopenia, thrombocytopenia, hypokalemia, and mild to moderate elevation of hepatic transaminases. ${ }^{1,2}$ The most common acute clinical complications of $\mathrm{CF}$ are secondary to involvement of the central nervous system, such as Guillain-Barré syndrome, and of the vision, including uveitis and retinitis. ${ }^{2}$ Chronically, development of syndromes affecting the joints is common, with long-lasting polyarthritis in 30 to $40 \%$ of cases. ${ }^{1,3}$ To date, vascular involvement has been described little in the medical literature in relation to $\mathrm{CF}$ and is normally restricted to Raynaud's phenomenon persisting beyond the acute phase. ${ }^{1,2}$ However, since the CHIKV outbreaks in 2015 and 2016, other vascular manifestations, such as deep venous thrombosis and lymphedema, have also been occasionally described in the medical literature. ${ }^{1,45}$ Below, we describe the case of a patient who developed lymphedema of upper and lower limbs after a laboratory-confirmed CHIKV infection.

\section{CASE DESCRIPTION}

The patient was a 33-year-old, brown-skinned female, who sought care at a walk-in health center (HC) with a history of fever $\left(>39^{\circ} \mathrm{C}\right)$, shivering, asthenia, nausea, vomiting, rash affecting the face and trunk, headaches, a stiff neck in the morning, and symmetrical polyarthritis of small and large joints (hips, shoulder, knees, elbows, fingers and toes).
A blood test revealed leukopenia $(2,190$ leukocytes $/ \mu \mathrm{L})$ and elevated hematocrit (56\%), probably caused by hemoconcentration secondary to dehydration. The patient was discharged from the $\mathrm{HC}$ with instructions to rest and take analgesics (paracetamol) and anti-inflammatories (naproxen), if needed for joint pain. Fifteen days later, she presented at the Rheumatology Service run by the Hospital Universitário Pedro Ernesto, Universidade do Estado do Rio de Janeiro (UERJ), complaining of exacerbation of the arthralgia and edema involving upper and lower limbs, despite regularly taking the medication prescribed, preventing her from working and practicing sport (muay thai). At this point, the patient no longer had fever or rash and was medicated with a combination of paracetamol-codeine and nimesulide. Around 7 days later, she returned to the Rheumatology Service, complaining of worsened edema in the upper limbs, especially on the right, and persistent arthralgia. At this consultation, laboratory tests were ordered to investigate her acute symmetrical polyarthritis and a hypothesis of $\mathrm{CF}$ was ventured and confirmed by reactive serology (Chikungunya antivirus ELISA IgG - Euroimmun ${ }^{\circledR},>22 \mathrm{UR} / \mathrm{mL}$ ). Since the patient's upper limb edema continued to worsen, she was referred to the Angiology Service at the Hospital Universitário Pedro Ernesto, Universidade do Estado do Rio de Janeiro (UERJ) for assessment. Physical examination found progressive edema involving all four limbs, with no improvement in response to rest, a positive Stemmer sign, and right upper and lower limbs with greater volume than the contralateral limbs (Figure 1). After discussing the case in a team meeting, color Doppler ultrasonography of the deep

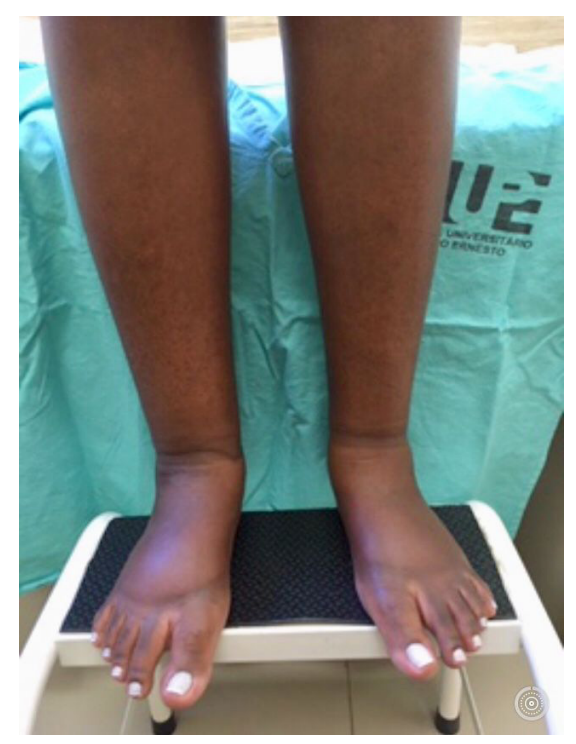

Figure 1. Lymphedema of lower limbs, more severe on the right. 


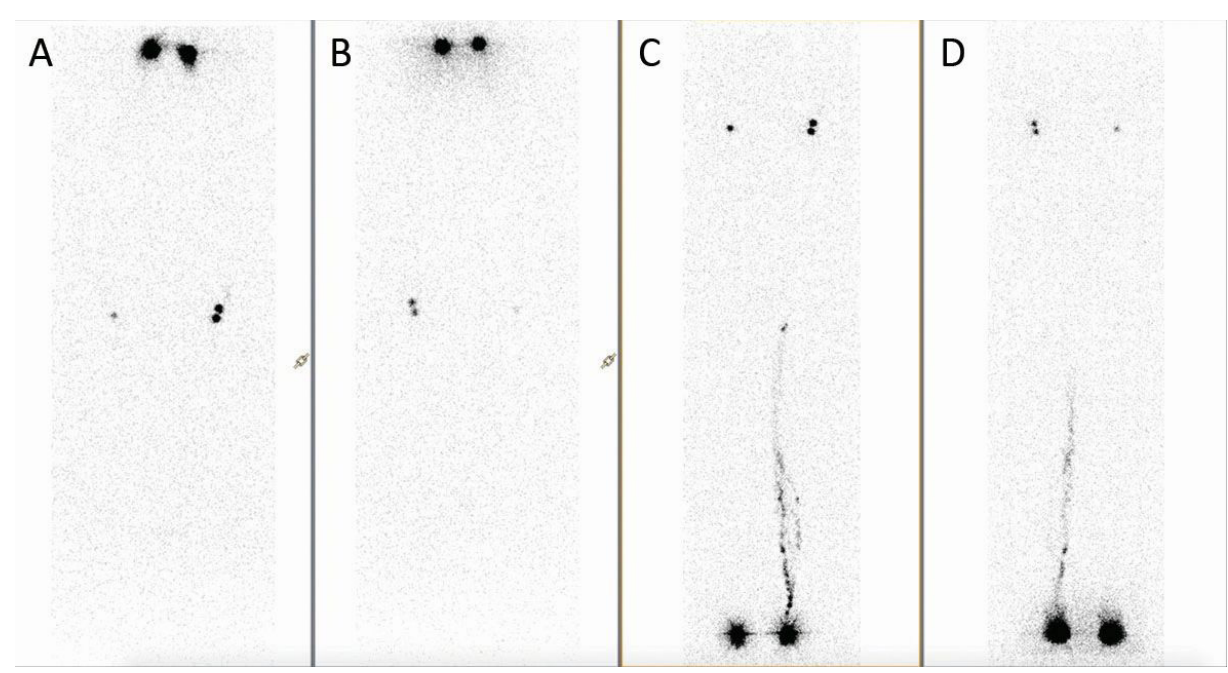

Figure 2. Semiquantitative lymphoscintigraphy of the upper limbs (A and B) and lower limbs (C and D). Images were captured 15, 30, 60, and 120 minutes after interdigital administration of $2.0 \mathrm{mCi} 99 \mathrm{~m}$ TC-Sn.

venous system of the upper and lower limbs was requested, to rule out deep venous thrombosis, and semiquantitative lymphoscintigraphy of the upper and lower limbs was performed to guide physiotherapy. Lymphoscintigraphy (Figure 2) demonstrated slow lymph flow in upper and lower limbs, and collateral lymph flow in the left leg and popliteal lymph node. The patient was referred to the Physiotherapy Service for complex physiotherapy.

\section{DISCUSSION}

Viral infections can provoke acute and chronic systemic inflammatory processes that often involve the osteoarticular system, causing acute polyarthritis that can sometimes become chronic. ${ }^{1-4}$ In $\mathrm{CF}$, approximately $48 \%$ of patients have chronic arthritis lasting at least 6 months. ${ }^{3}$ This has been confirmed in the laboratory by persistent elevation of certain inflammatory markers, such as interleukin-6, for example. ${ }^{3}$ While there are very few references in the medical literature on the association between CHIKV and acute and chronic vascular complications, ${ }^{1,4,5}$ the recent outbreak of $\mathrm{CF}$ on the American continent, in 2015, provoked a considerable increase in both incidence and prevalence of this arbovirus and, as a result, of its less common complications. The emergence of lymphedema involving lower and upper limbs in patients who have had CF probably has multifactorial origins. These patients may have a reduced lymphatic reserve, caused by anatomic and/or dynamic, congenital and/or acquired changes, with the result that the system is unable to deal with the demand caused by increase lymph production secondary to the articular inflammatory process characteristic of infection by CHIKV. Additionally, these patients very often have movement chronically limited by intense pain, or may even be practically restricted to bed, reducing muscle contractions in the limbs and reducing one of the physiological mechanisms of lymph drainage. ${ }^{6}$ In the case described, the patient practiced martial arts regularly (muay thai) and was employed as a hairdresser, but had to cease both activities because of incapacitating arthralgia. Restricted movement can also provoke increase in body mass index, which can be another factor in maintenance of lymphedema, since it can limit patients' return to their daily activities even more.

\section{CONCLUSIONS}

The vascular complications of CF began to be described sporadically after the outbreaks in 2015 and 2016. Thee pathophysiology of lymphedema secondary to infection by CHIKV has not yet been elucidated, but it clearly involves several different mechanisms which, in combination, can provoke or exacerbate lymphatic dysfunction and, therefore, induce a chronic condition.

\section{REFERENCES}

1. Marques MA, Adami de Sá FP, Lupi O, Brasil P, von Ristow A. Deep venous thrombosis and chikungunya virus. J Vasc Bras. 2017;16(1):60-2. http://dx.doi.org/10.1590/1677-5449.009616. PMid:29930626.

2. Staples JE, Breiman RF, Powers AM. Chikungunya fever: an epidemiological review of a re-emerging infectious disease. Clin Infect Dis. 2009;49(6):942-8. http://dx.doi.org/10.1086/605496. PMid:19663604. 
3. Khoury VJ, Camilo PR. Chikungunya virus (CHIKV): what can be expected after the acute phase? Reumatol Clin. 2016;12(1):1-3. http://dx.doi.org/10.1016/j.reuma.2015.12.002. PMid:26781826.

4. Marques MA, von Ristow A. Linfedema e febre chicungunha. J Vasc Bras. 2017;16(2):178-9. http://dx.doi.org/10.1590/16775449.003717. PMid:29930643.

5. Ramacciotti E, Agati LB, Aguiar VCR, et al. Zika and Chikungunya virus and risk for venous thromboembolism. Clin Appl Thromb Hemost. 2019;25:1-5. http://dx.doi.org/10.1177/1076029618821184. PMid:30808213.

6. Pereira de Godoy JM. Fisiologia do sistema linfático. In: Guedes HJ No, Quilici Belczak CE, editors. Linfologia: diagnóstico, clínica e tratamento. São Caetano do Sul: Yendis Editora; 2009. p. 57-62.
Correspondence Marcos Arêas Marques Rua Assunção, 217/704 - Botafogo CEP 22251-030 - Rio de Janeiro (RJ), Brasil

Tel.: (21) 99859-0160

E-mail:mareasmarques@gmail.com

Author information MAM - Physician, Serviço de Angiologia, Hospital Universitário Pedro Ernesto, Universidade Estadual do Rio de Janeiro (UERJ); Serviço de Cirurgia Vascular, Hospital Universitário Gafrée e Guinle, Universidade Federal do Estado do Rio de Janeiro (UNIRIO).

ALMM - Physician, Serviço de Angiologia, Hospital Universitário Pedro Ernesto, Universidade Estadual do Rio de Janeiro (UERJ). JMV - Physician, Serviço de Angiologia, Hospital Universitário Pedro Ernesto, Universidade Estadual do Rio de Janeiro (UERJ).

FRC - Resident physician, Serviço de Medicina Nuclear, Instituto Nacional do Câncer. HJGN - PhD. Professor, Discipline of Vascular and Endovascular Surgery, Escola Paulista de Medicina.

Author contributions Conception and design: MAM, ALMM, HJGN Analysis and interpretation: MAM, JMV, HJGN, FRC Data collection: MAM, ALMM Writing the article: MAM, HJGN Critical revision of the article: MAM, JMV, HJGN, FRC, ALMM Final approval of the article*: MAM, JMV, HJGN, FRC, ALMM Statistical analysis: N/A Overall responsibility: MAM

*All authors have read and approved of the final version of the article submitted to J Vasc Bras. 